\title{
PENGARUH UPAH MINIMUM PROVINSI, INVESTASI, DAN PDRB TERHADAP PENYERAPAN TENAGA KERJA DI INDONESIA
}

\section{Sapriansah Ali Nur Iksan*, Zainal Arifin, M. Sri Wahyudi Suliswanto}

Program Studi Ekonomi Pembangunan, Fkaultas Eknomi dan Bisnis, Universitas Muhammadiyah Malang, J1.Raya Tlogomas No.246 Malang, Indonesia

* Corresponding author:

\begin{tabular}{|c|c|}
\hline Artikel Info & Abstract \\
\hline Article history: & This study aims to describe the contribution and examine the \\
\hline Received 14 August 2019 & effect of provincial minimum wages, investment and GRDP \\
\hline Revised 20 September 2019 & on labor absorption in Indonesia. The data used in this study \\
\hline Accepted 20 October 2019 & uses panel data, namely a combination of time series and \\
\hline Available online 15 February & cross section, in this study using 34 provinces in Indonesia in \\
\hline 2020 & $\begin{array}{l}\text { 2013-2017. This study uses the Fixed Effect test. The results } \\
\text { showed that the highest average contribution of labor }\end{array}$ \\
\hline $\begin{array}{l}\text { Keyword: provincial minimum } \\
\text { wage, investment, GRDP, labor } \\
\text { absorption }\end{array}$ & $\begin{array}{l}\text { absorption was in the province of East Java, investment was } \\
\text { in the province of West Java, the provincial GDP and } \\
\text { minimum wages were in the province of DKI Jakarta. } \\
\text { Meanwhile, the estimation results show that the provincial }\end{array}$ \\
\hline JEL Classification & minimum wage variable has a positive and significant effect \\
\hline $\mathrm{D} 00, \mathrm{E} 22, \mathrm{E} 24$ & $\begin{array}{l}\text { on labor absorption, the investment variable has a negative } \\
\text { and insignificant effect on labor absorption, while the GRDP } \\
\text { variable has a positive and significant effect on labor } \\
\text { absorption in Indonesia. }\end{array}$ \\
\hline
\end{tabular}

\section{PENDAHULUAN}

Indonesia merupakan negara berkembang dan memiliki jumlah penduduk terbesar ke 4 di dunia yang tentunya tidak dapat terlepaskan dari masalah yang terkait dengan ketenagakerjaan. Masalah ketenagakerjaan yang sering dihadapi di indonesia yaitu pesatnya jumlah angkatan kerja yang tidak di imbangi dengan adanya jumlah lapangan pekerjaan yang tersedia. Menurut Nofandillah (2018) masalah dari banyaknya jumlah angkatan kerja yaitu banyaknya jumlah penduduk yang terus mengalami peningkatan sehingga lapangan pekerjaan tidak dapat menampung seluruh angkatan kerja, jumlah lapangan kerja yang sedikit di sebabkan karena masih belom meratanya pembangunan yang dilakukan. Pembangunan nasional yang dilakukan di indonesia tidak dapat terlepas dari pembangunan daerah karena wilayah di Indonesia terdiri dari berbagai provinsi, kabupaten/kota serta daerah yang lebih kecil. Kegiatan pembangunan yang sedang dilakukan atau direncanakan harus dapat dirasakan oleh masyarakat kecil, karena pembangunan merupakan proses multidimensi dan dapat berkembang dengan mencakup adanya perubahan yang penting di dalam akselerasi pertumbuhan ekonomi, struktur sosial, pengangguran, kesenjangan, dan kemiskinan Todaro (2000).

Berdasarkan Badan Pusat Statistik bahwa angkatan kerja pada tahun 2013 sebesar 120,17 dan pada tahun 2014 sebesar 121,87 naik dari tahun sebelumnya sebesar 1,7 juta kemudian pada tahun 2015 jumlah angkatan kerja juga meningkat dari tahun sebelumnya sebesar 510 ribu orang atau 122,38 juta kemudian di ikuti tahun berikutnya pada 2016 sebesar 125,44 juta angkatan kerja, begitu juga pada tahun 2017 sebesar 128,06 juta jiwa, ini artinya bahwa angkatan kerja setiap tahun selalu mengalami peningkatan. 
Salah satu upaya yang perlu dilakukan oleh pemerintah dalam menangani masalah ketenagakerjaan yaitu dengan cara memperbaiki tingkat upah yang diterima masyarakat dengan kebijakan upah minimum, dengan adanya kebijakan upah minimum yang dilakukan yaitu upaya dalam rangka meningkatkan upah perkapita para pekerja, sehingga tingkat upah rata-rata para tenaga kerja dapat meningkat. Menurut Atifatur (2018) upah adalah imbalan dari hasil kerja yang dilakukan seseorang kepada perusahaan. Meningkatnya upah ditandai dengan adanya kenaikan jumlah permintaan barang dan jasa, oleh sebab itu naiknya jumlah permintaan barang dan jasa dapat menyebabkan jumlah dari produksi dapat meningkat, yang pada akhirnya dapat menyebabkan peningkatan jumlah tenaga kerja yang diperlukan oleh perusahaan. Kenaikan upah memang dapat meningkatkan kesempatan kerja, karena dengan naiknya tingkat upah yang dilakukan diharapkan juga akan ada peningkatan kesempatan kerja melaui peningkatan konsumsi, namun dalam berbagai kasus yang terjadi upah justru dapat berpengaruh yang negatif terhadap penyerapan tenaga kerja. Menurut Kuncoro (2000) berpendapat bahwa kenaikan upah dapat menyebabkan turunnya kuantitas tenaga kerja yang diminta, jika tingkat upah mengalami kenaikan sementara harga input yang lainnya tetap maka harga dari tenaga kerja akan cenderung mahal dari input yang lainnya, sehingga dapat menyebabkan para pengusaha untuk mengurangi dan mengganti tenaga kerja yang mahal dengan input lain yang lebih murah untuk mempertahankan keuntungan. Kenaikan upah yang dilakukan juga dapat mempengaruhi para pengusaha untuk menaikan harga produksi barangnya, sehimgga akan berdampak pada konsumen yang cenderung untuk menurunkan tingkat konsumsinya. Hal ini akan berdampak pada produk yang tidak terjual, sehingga produsen akan mengurangi jumlah produksinya dan pada akhirnya dapat menyebabkan pengurangan jumlah tenaga kerja yang dibutuhkan. Selain kebijakan menaikan upah, banyak beberapa hal yang perlu mendapatkan perhatian dari pemerintah untuk menangani masalah ketenaga kerjaan yaitu dengan melakukan investasi, karena investasi secara tidak langsung juga dapat menaikan kapasitas produksi dengan meningkatnya jumlah produksi yang dihasilkan tentu akan berdampak pada penambahan jumlah tenaga kerja yang dibutuhkan. Menurut teori Keynes mengatakan bahwa cara mengurangi pengangguran yaitu dengan memperbanyak investasi misalnya mesin karena mesin membutuhkan operator sehingga secara langsung ataupun tidak akan menyerap tenaga kerja dan dapat membuka lapangan pekerjaan baru. Selain itu konsumsi harus sama dengan pendapatan yang mereka peroleh, karena dengan banyaknya konsumsi yang dilakukan akan meningkatkan dan memperbanyak output yang diminta, apabila outputnya banyak maka upah yang diperoleh akan naik sehingga daya beli mereka dapat meningkat.

Selain investasi yaitu dengan meningkatkan produk domestik regional bruto (PDRB), karena produk domestik regional bruto merupakan nilai tambah dari barang dan jasa yang dihasilkan dari berbagai unit produksi atau sektor yang mereka peroleh dalam jangka waktu tertentu. Produk domestik regional bruto (PDRB) juga dapat mempengaruhi pada jumlah angkatan kerja 
yang bekerja dengan sumsi apabila nilai produk domestik regionalnya meningkat, maka nilai tambah jumlah output dan penjualan yang di hasilkan dalam seluruh unit ekonomi di suatu wilayah juga akan meningkat, sehingga dapat menaikan jumlah permintaan tenaga kerja di setiap daerah. Oleh sebab itu keberhasilan pemerintah dalam pembangunan dapat dinilai seberapa besar pemerintah mapu menciptakan lapangan pekerjaan sehingga dapat mengurangi jumlah pengangguran yang ada, dengan terciptanya lapangan pekerjaan yang baru tentu akan berdampak pada penyerapan tenaga kerja. Banyaknya tenaga kerja yang terserap juga akan meningkatkan kesejahteraan masyarakat, oleh sebab itu kebijakan pemerintah perlu dilakukan untuk memperbaiki perekonomian di setiap daerah sehingga masyarakat dapat menikmati pembangunan dengan merata agar tidak terjadi ketimpangan, kemiskinan, dan pengangguran, oleh karena itu diperlukan upaya dalam mengatasi masalah tersebut terutama ketenagakerjaan.

Berdasarkan masalah yang telah diuraikan diatas maka dapat dirumuskan masalah dalam penelitian ini yaitu gambaran kontribusi dan pengaruh upah minimum provinsi, investasi dan PDRB terhadap penyerapan tenaga kerja di Indonesia.

Penelitian yang dilakukan oleh Roni Akmal (2010) dengan judul "Faktor-faktor Penyerapan Tenaga Kerja Di Indonesia" hasil penelitian menyatakan bahwa upah minimum provinsi berpengaruh signifikan terhadap penyerapan tenaga kerja di indonesia dan berhubungan positif pada tahun 2003-2007, ketika terjadi kenaikan sebesar 1\% maka akan meningkatkan penyerapan tenaga kerja sebesar 0,04 persen. Sementara investasi mempunyai pengaruh positif signifikan terhadap penyerapan tenaga kerja, setiap investasi naik sebesar $1 \%$ maka dapat meningkatkan penyerapan tenaga kerja sebesar 0,01\%. Namun dalam berbagai kasus terkadang investasi tidak selalu menunjukkan adanya kenaikan dan bertambahnya penyerapan tenaga kerja.

Penelitian yang dilakukan oleh Budi Utami (2009) mengenai "Pengaruh upah minimmum kabupaten, Produk Domestik Regional Bruto, Angkatan Kerja dan Investasi Terhadap Kesempatan Kerja Di kabupaten Jember" hasil penelitian menyatakan bahwa upah minimum tidak berpengaruh signifikan terhadap kesempatan kerja di Kabupaten Jember, sedangkan PDRB, angkatan kerja dan investasi berpengaruh positif dan signifikan terhadap penyerapan tenaga kerja di Kabupaten Jember.

Penelitian yang dilakukan oleh Indra Dewa dan Natha (2015) mengenai variabel "Pengaruh Inflasi, PDRB, dan Upah Minimum Terhadap Penyerapan Tenaga Kerja Di Provinsi Bali" hasil penelitian menyatakan bahwa secara simultan inflasi, PDRB, dan upah minimum berpengaruh signifikan terhadap penyerapan tenaga kerja di Provinsi Bali pada tahun 19942013. Sedangkan secara partial PDRB dan upah minimum berpengaruh positif dan signifikan kemudian inflasi berpengaruh negatif dan tidak signifikan terhadap penyerapan tenaga kerja di Provnsi Bali.

Penelitian yang dilakukan oleh Rizqi Wasilaputri (2016) dengan penelitian "Pengaruh Upah Minimum Provinsi, PDRB dan Investasi Terhadap Penyerapan Tenaga Kerja Di Pulau Jawa" hasil penelitian menyatakan bahwa investasi berpengaruh negatif dan tidak signifikan, 
sedangkan upah minimum provinsi berpengaruh negatif dan signifikan terhadap penyerapan tenaga kerja di Pulau Jawa pada tahun 2010-2014.

Berdasarkan penelitian yang telah di lakukan oleh beberapa peneliti sebelumnya maka peneliti tertarik melakukan penelitian mengenai variabel Upah Minimum Provinsi, Investasi dan PDRB Terhadap Penyerapan Tenaga Kerja di Indonesia.

\section{Gambar 1. Kerangka Pemikiran}

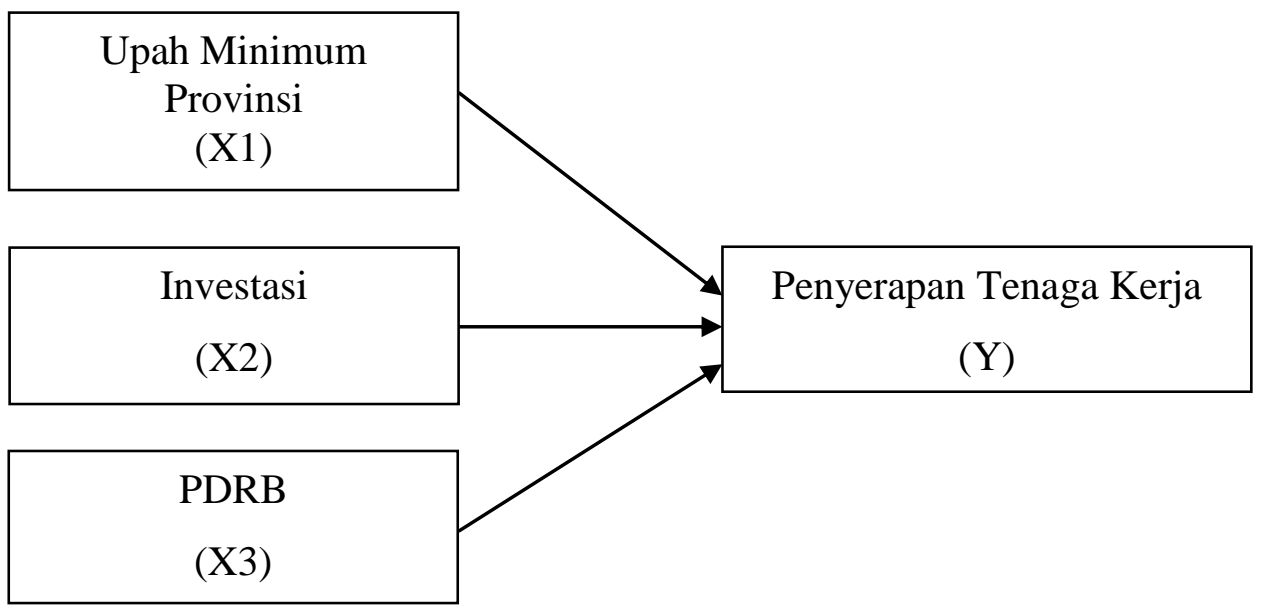

Berdasarkan uraian diatas maka penulis membuat suatu hipotesis dalam penelitian ini adalah "Diduga ada pengaruh antara variabel Upah Minimum Provinsi, Investasi, dan PDRB terhadap Penyerapan Tenaga Kerja di Indonesia pada tahun 2013-2017".

\section{METODE PENELITIAN}

Penelitian yang dilakukan yaitu di 34 Provinsi di Indonesia pada Tahun 2013-2017, jenis penelitian bersifat deskriptif kuantitatif dengan menggunakan suatu gambaran yang sistematis dan akurat melalui data yang ada dan bersumber dari jurnal serta studi pustaka yang mendukung pada penelitian tersebut. Data yang digunakan yaitu sekunder yang di peroleh dari Badan Pusat Statistik, variabel yang digunakan yaitu variabel bebas diantaranya Upah Minimum Povinsi, Investasi Dan PDRB sementara variabel terikatnya adalah Penyerapan Tenaga Kerja.

Metode dalam penelitian ini menggunakan data panel yang merupakan gabungan dari time series dan cross section, data time series diperoleh dari tahun 2013-2017 dan data cross section di peroleh dari 34 provinsi di Indonesia.

\section{Rumus regresi data panel}

Dimana:

$$
\log Y_{i t}=\alpha+\beta_{i t} X_{1 i t}+\beta_{i t} X_{2 i t}+\beta_{i t} X_{3 i t}+\mathrm{e}
$$

$\log Y_{i t} \quad=$ Penyerapan Tenaga Kerja;

$\propto \quad=$ Konstanta;

$\beta_{1} \beta_{2} \beta_{3} \quad=$ Koefisien Garis Regresi;

$X_{1} \quad=$ Upah Minimum Provinsi;

$X_{2} \quad=$ Investasi; 


\begin{tabular}{|c|c|}
\hline$X_{3}$ & $=\mathrm{PDRB}$ \\
\hline i & $=$ Data Cross Section 34 Provinsi; \\
\hline 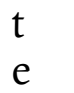 & $\begin{array}{l}=\text { Data Time Series 2013-2017; } \\
=\text { Error }\end{array}$ \\
\hline
\end{tabular}

Tahap dalam analisis sebagai berikut: a).menentukan metode estimasi model regresi yang dapat menggunakan eviews 9 dengan melakukan tiga pendekatan antara lain: 1) Metode Pooled Least Square (PLS) atau Commont Effect yaitu pendekatan sederhana dalam data panel karena terkombinasi dari data time series dan cross section metode ini mengabaikan antara dimensi individu dan waktu, oleh sebab itu dapat diasumsikan bahwa perilaku dalam data kurun waktu adalah sama. 2) Metode Fixed Effect yaitu menggunakan asumsi bahwa perbedaan antar individu dapat diakomodasikan dari perbedaan intersepnya namun slopnya tetap sama antar variabel. 3) Metode Random Effect yaitu mengestimasi data panel yang dimana variabel ada gangguan yang saling berhubungan baik antar individu maupun waktu, pada model ini terdapat perbedaan intersepnya yang diakomodasikan oleh error term. b) pemilihan model terbaik yaitu 1) Uji Chow yang merupakan uji dimana untuk menentukan Commont Effect atau Fixed Effect yang akan dipilih. Hipotesis dalam uji chow yaitu $H_{0}=$ Commont Effect, $H_{1}=$ Fixed Effect dengan ketentuan apabila Cross-Section Chi-Square $<\alpha=0,05$ maka $H_{0}=$ ditolak, $H_{1}=$ diterima dan apabila Cross-Section Chi-Square $>\alpha=0,05$ maka $H_{0}=$ diterima $H_{1}=$ ditolak. 2) Uji Hausman merupakan uji yang digunakan untuk memilih Fixed Effect atau Random Effect yang dipilih. Hipotesis dalam uji hausman yaitu $H_{0}=$ Random Effect, $H_{1}=$ Fixed Effect dengan ketentuan apabila Cross-Section Chi-Square $<\alpha=0,05$ maka $H_{0}=$ ditolak, $H_{1}=$ diterima dan apabila Cross-Section Chi-Square $>\alpha=0,05$ maka $H_{0}=$ diterima $H_{1}=$ ditolak. 3) Uji Langrange Multiplier merupakan uji dimana untuk menentukan Random Effect atau Commont Effect yang akan dipilih. Hipotesis dalam uji langrangge multipllier yaitu $H_{0}=$ Commont Effect, $H_{1}=$ Random Effect dengan ketentuan apabila Cross-Section Chi-Square $<\alpha=$ 0,05 maka $H_{0}=$ ditolak, $H_{1}=$ diterima dan apabila Cross-Section Chi-Square $>$ $\alpha=0,05$ maka $H_{0}=$ diterima $H_{1}=$ ditolak.

\section{HASIL DAN PEMBAHASAN}

Secara astronomis Indonesia terletak antara $6^{\circ} 08^{\prime}$ Lintang Utara dan $11^{\circ} 15^{\prime}$ Lintang Selatan dan antara $95^{\circ} 45^{\prime}-141^{\circ} 05^{\prime}$ Bujur Timur yang dilalui oleh garis equator atau garis khatulistiwa yang terletak pada garis lintang $0^{\circ}$. Berdasarkan letak geografisnya kepulauan di Indonesia berada di antara Benua Asia dan Benua Australia serta diantara Samudra India dan Samudra Pasifik. Indonesia memiliki luas daerah yaitu sebesar $1.910 .931,32 \mathrm{~km}^{2}$ dengan jumlah pulau sebanyak 17.504, batas ujung barat indonesia yaitu Sabang sementara batas pada ujung timur Indonesia yaitu Merauke sedangkan batas ujung utara adalah pulau Miangas dan batas ujung selatan adalah pulau Rote. Indonesia berada pada iklim tropis dan berada pada belahan timur bumi dan negara yang memiliki 3 daerah waktu yaitu WIB, WITA, WIT. 
Indonesia terdiri dari 34 provinsi yang terletak di 5 pulau besar yaitu Pulau Jawa, Pulau Sumatra, Pulau Kalimantan, Pulau Sulawesi, dan Pulau Papua, kemudian terdiri dari 4 kepulauan yaitu Kepulauan Riau, Kepulauan Bangka, Kepulauan Nusa Tenggara, Kepulauan Maluku. Penduduk Indonesia pada tahun 2013 mencapai 248.8 juta jiwa, 2014 mencapai 252.2 juta jiwa, 2015 mencapai 255.5 juta jiwa, 2016 mencapai 258.7 juta jiwa dan pada 2017 mencapai 261.9 juta jiwa, ini artinya bahwa jumlah penduduk setiap tahunnya mengalami peningkatan. Jumlah penduduk masih diperkirakan meningkat sebesar 32.6 juta dalam kurun waktu 10 tahun (20102020).

\section{Gambar 2. Peta Indonesia}

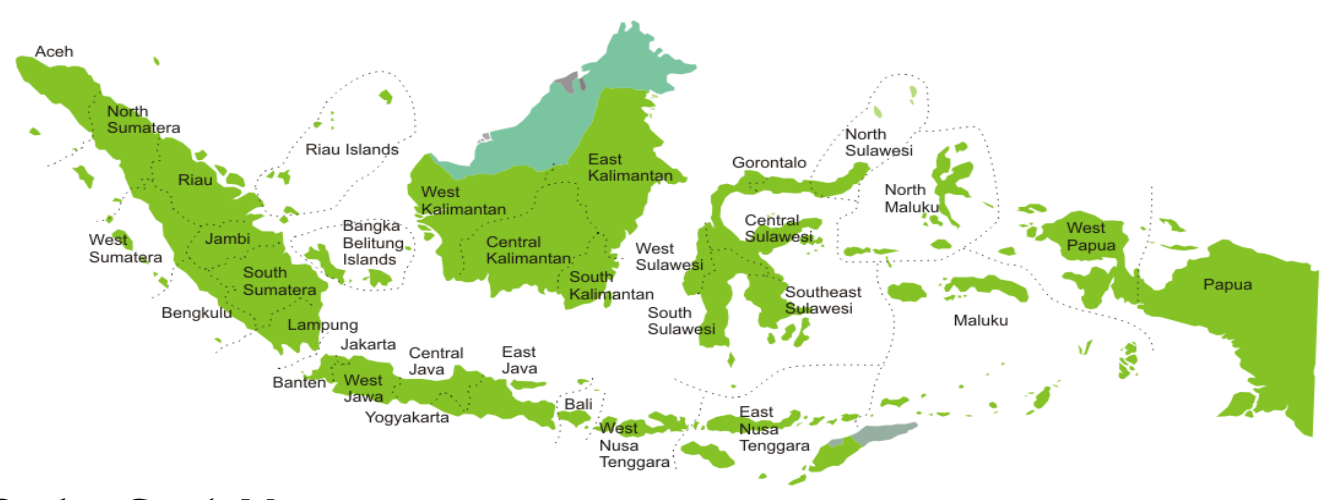

Sumber: Google Map

Jumlah penduduk terbanyak di indonesia masih berada di Jawa yaitu di daerah Jawa Barat, Jawa Timur dan Jawa Tengah sementara jumlah penduduk terendah berada pada luar Jawa yaitu Papua Barat. Sedangkan kepadatan penduduk indonesia tertinggi masih berada pada provinsi yaitu DKI Jakarta, Jawa Barat, Banten, sedangkan kepadatan penduduk terendah yaitu Papua dan Papua Barat.

Berdasarkan hipotesis permasalahan yang ada yaitu untuk mengetahui pengaruh upah minimum provinsi, investasi, dan PDRB terhadap penyerapan tenaga kerja. Penelitian yang dilakukan menggunakan data panel yaitu gabungan antara time series dan cross section, dengan menggunakan data panel dapat teridentifikasi antara variabel bebas dan variabel terikat. Pengujian data panel dapat dilakukan dengan menggunakan Uji F Statistik, Uji t Statistik dan Uji Koefisien Determinasi $\left(R^{2}\right)$.

Kemudian melakukan analisis data yaitu Pengaruh Upah Minimum Provinsi, Investasi dan PDRB Terhadap Penyerapan Tenaga Kerja di Indonesia dengan variabel bebasnya yaitu upah minimmum provinsi, investasi dan PDRB, sedangkan variabel terikatnya adalah penyerapan tenaga kerja, dalam pemilihan yang dilakukan menggunakan regresi data panel terdapat berbagai uji yaitu Commont Effect, Fixed Effect dan Random Effect kemudian untuk memilih model yang tepat untuk digunakan terdapat 
beberapa uji yaitu Uji Chow, Uji Hausman dan Uji Langrange Multiplier dan hasil pengujian terdapat di tabel berikut :

\section{Tabel 1. Hasil Regresi Data Panel}

\begin{tabular}{|c|r|r|}
\hline \multicolumn{3}{|c|}{ CE } \\
\hline Variable & Coefficient & Prob. \\
\hline UMP & -3.922525 & 0.0000 \\
INVESTASI & 0.000444 & 0.9777 \\
PDRB & 10.61279 & 0.0000 \\
R-squared & 0.798092 & \\
F-statistic & 218.7194 & \\
Prob(F-statistic) & 0.000000 & \\
\hline \multicolumn{3}{|r|}{ FE } \\
\hline UMP & 0.169971 & 0.0013 \\
INVESTASI & -0.004752 & 0.0857 \\
PDRB & 2.329450 & 0.0000 \\
R-squared & 0.999155 & \\
F-statistic & 4370.589 & \\
Prob(F-statistic) & 0.000000 & \\
\hline \multicolumn{2}{|c|}{ RE } \\
\hline UMP & 0.038275 & 0.2430 \\
INVESTASI & -0.002289 & 0.0116 \\
PDRB & 4.027361 & 0.0000 \\
R-squared & 0.352471 & \\
F-statistic & 30.11975 & \\
Prob(F-statistic) & 0.000000 & \\
\hline
\end{tabular}

Sumber: Data diolah, Eviews 9

Berdasarkan tabel 1 diketahui bahwa hasil regresi menggunakan Common Effect dengan nilai koefisien determinasi R-squared yaitu sebesar 0.798092 artinya variabel bebas dapat dijelaskan variabel terikat sebesar $79,80 \%$, sedangkan sisanya dijelaskan oleh variabel lain diluar model ini.

Berdasarkan hasil regresi menggunakan Fixed Effect dengan nilai koefisien determinasi R-squared yaitu sebesar 0.999155 artinya variabel bebas dapat dijelaskan oleh variabel terikat sebesar 99,91\%, sedangkan sisanya dijelaskan oleh variabel lain diluar model.

Berdasarkan hasil regresi menggunakan Random Effect dengan nilai koefisien determinasi R-squared yaitu sebesar 0.352471 artinya variabel bebas dapat dijelaskan oleh variabel terikat sebesar 35,24\%, sedangkan sisanya dijelaskan oleh variabel lain diluar model.

\section{Pemilihan Model Terbaik}

Tabel 2. Hasil Uji Chow

\begin{tabular}{|l|r|r|r|}
\hline \multicolumn{1}{|c|}{ Effects Test } & Statistic & d.f. & Prob. \\
\hline Cross-section F & 959.461899 & $(33,133)$ & 0,0000 \\
Cross-section Chi-square & 931.042881 & 33 & 0,0000 \\
\hline
\end{tabular}


Sumber: Data diolah, Eviews 9

Dalam pemilihan model Common Effect atau Fixed Effects yaitu dengan menggunakan Uji Chow, apabila nilai Cross-section Chi-square < 0,05 maka model yang tepat untuk digunakan yaitu Fixed Effect, sebaliknya apabila nilai Cross-section Chi-square $>0,05$ maka model yang tepat untuk digunakan yaitu Common Effect. Berdasarkan hasil uji Chow dapat diketahui bahwa Cross-section Chi-Square sebesar 0,0000 maka model yang tepat untuk digunakan yaitu Fixed Effect.

\section{Tabel 3. Uji Hausman}

\begin{tabular}{|l|c|c|l|}
\hline Test Summary & Chi-Sq. Statistic & Chi-Sq. d.f. & Prob. \\
\hline $\begin{array}{l}\text { Cross-section } \\
\text { random }\end{array}$ & 127.084494 & 3 & 0,0000 \\
\hline
\end{tabular}

Sumber: Data diolah, Eviews 9

Dalam pemilihan model Fixed Effect atau Random Effect yaitu dengan menggunakan Uji Hausman, apabila nilai Cross-section Chi-square < 0,05 maka model yang tepat untuk digunakan yaitu Fixed Effect, sebaliknya apabila nilai Cross-section Chi-square $>0,05$ maka model yang tepat untuk digunakan yaitu Random Effect. Berdasarkan hasil uji Hausman dapat diketahui bahwa nilai Cross-section random sebesar 0,0000 maka model yang tepat untuk digunakan yaitu Fixed Effect.

Tabel 4. Uji Lagrange Multiplier (Breusch-Pagan)

\begin{tabular}{|l|r|r|r|}
\hline \multirow{2}{*}{} & \multicolumn{3}{|c|}{ Test Hypothesis } \\
\cline { 2 - 4 } & Cross-section & Time & \multicolumn{1}{c|}{ Both } \\
\hline \multirow{3}{*}{ Breusch-Pagan } & 79.77619 & 2.748609 & 82.52480 \\
\cline { 2 - 4 } & $(0.0000)$ & $(0.0973)$ & $(0.0000)$ \\
\hline
\end{tabular}

Sumber: Data diolah, Eviews 9

Dalam pemilihan model Common Effect atau Random Effect yaitu dengan menggunakan Uji LM Breunch-pagan, apabila nilai Cross-section Chi-square $<0,05$ maka model yang tepat untuk digunakan yaitu Random Effect, sebaliknya apabila nilai Cross-section Chi-square $>0,05$ maka model yang tepat untuk digunakan yaitu Common Effect. Berdasarkan hasil uji Lagrange Multiplier yang telah dilakukan menunjukkan bahwa BreuschPagan sebesar 0,0000 maka model yang tepat untuk digunakan yaitu Random Effect.

Dalam pemilihan model yang dilakukan menggunakan Uji Chow, dan Uji Hausman model yang tepat digunakan yaitu Fixed Effect.

Tabel 5. Hasil fixed Effect

\begin{tabular}{|c|r|r|r|r|}
\hline Variable & Coefficient & Std. Error & t-Statistic & Prob. \\
\hline \hline C & 2557046. & 101055.4 & 25.30340 & 0.0000 \\
UMP & 0.169971 & 0.051688 & 3.288388 & 0.0013 \\
INVESTASI & -0.004752 & 0.002744 & -1.731562 & 0.0857 \\
\hline
\end{tabular}




\begin{tabular}{|c|c|c|c|c|}
\hline \multicolumn{4}{|c|}{$\begin{array}{r}\text { Pengaruh Upah Minimum Provinsi, Investasi, Dan Pdrb Terhadap } \\
\text { Ppenyerapan Tenaga Kerja Di Indonesia }\end{array}$} & $\begin{array}{l}\text { Iksan } \\
\text { Arifin } \\
\text { Wahyudi }\end{array}$ \\
\hline PDRB & 2.329450 & 0.420007 & 5.546214 & 0.0000 \\
\hline
\end{tabular}

Maka diperoleh regresi sebagai berikut :

$\mathrm{Y}=2557046+0.169971 * \mathrm{UMP}-0.004752 *$ Investasi $+2.329450 * \mathrm{PDRB}$

Dari persamaan diatas dapat di interpretasikan sebagai berikut :

1) Jika UMP (X1), Investasi (X2) dan PDRB (X3) dianggap konstan atau nol maka akan meningkatkan penyerapan tenaga kerja sebesar 2.557,046 juta jiwa.

2) Jika variable UMP (X1) naik $1 \%$ maka akan meningkatkan penyerapan tenaga kerja sebesar 0.169971 ribu jiwa

3) Jika variable Investasi (X2) turun $1 \%$ maka akan menurunkan penyerapan tenaga kerja sebesar 0.004752 ribu jiwa.

4) Jika variable PDRB (X3) naik 1\% maka akan meningkatkan penyerapan tenaga kerja sebesar 2.329450 juta jiwa.

\section{Pengujian Simultan (F-Statistik)}

Uji f-statistik merupakan uji yang digunakan untuk mengetahui pengaruh dari semua variabel secara bersama-sama yaitu variabel independen (variabel bebas) antara lain Upah Minimum Provinsi, Investasi, dan Produk Domestik Regional Bruto terhadap variabel dependen ( variabel terikat) yaitu Penyerapan Tenaga Kerja.

Berdasarkan hasil dapat diketahui F-statistik sebesar 4370.589 dan nilai F-tabel sebesar 3,05 sedangkan probabilitas F-statistik yaitu 0,00000 maka nilai tersebut lebih kecil dari 0,05 sehingga menolak $H_{O}$ dan menerima $H_{1}$, yang artinya bahwa semua variabel Upah Minimum Provinsi, Investasi dan Produk Domestik Regional Bruto secara bersama-sama (simultan) mempengaruhi Penyerapan Tenaga Kerja.

\section{Pengujian Parsial (t-Statistik)}

Uji t-statistik digunakan untuk mengetahui pengaruh dari semua variabel secara sendiri-sendiri yaitu variabel independen (variabel bebas) antara lain Upah Minimum Provinsi, Investasi, dan Produk Domestik Regional Bruto terhadap variabel dependen (variabel terikat) yaitu Penyerapan Tenaga Kerja.

Berdasarkan hasil menunjukkan Upah Minimum Provinsi memiliki tstatistik sebesar 3.288388 dan nilai t-tabel sebesar 1.97436 dengan nilai probabilitas sebesar 0.0013 nilai tersebut lebih kecil dari 0,05, sehingga dapat dikatakan bahwa variabel Upah Minimum Provinsi secara parsial berpengaruh positif dan signifikan terhadap Penyerapan Tenaga Kerja.

Berdasarkan hasil menunjukkan Investasi memiliki t-statistik sebesar 1.731562 dan nilai t-tabel sebesar 1.97436 dengan nilai probabilitas sebesar 0.0857 nilai tersebut lebih besar dari 0,05 , sehingga dapat dikatakan bahwa 
variabel Investasi secara parsial berpengaruh negatif dan tidak signifikan terhadap Penyerapan Tenaga Kerja.

Berdasarkan hasil menunjukkan Produk Domestik Regional Bruto memiliki t-statistik sebesar 5.546214 dan nilai t-tabel sebesar 1.97436 dengan nilai probabilitas sebesar 0.0000 nilai tersebut lebih kecil dari 0,05 , sehingga dapat dikatakan bahwa variabel Produk Domestik Regional Bruto secara parsial berpengaruh positif dan signifikan terhadap Penyerapan Tenaga Kerja.

\section{Pengujian Koefisien Determinasi $\left(R^{2}\right)$}

Koefisien determinasi $R^{2}$ digunakan untuk mengetahui besarnya pengaruh antara variabel independen terhadap variabel dependen, koefisien dapat menunjukan besaran persentase variasi antara variabel independen yang mampu menjelaskan variasi variabel dependen

Hasil dari R-squared yaitu sebesar 0.999155 artinya nilai ini menunjukkan bahwa 99,91\% variabel bebas mampu menjelaskan variabel terikat, sedangkan sisanya di jelaskan oleh variabel lain diluar model.

Berdasarkan hasil yang telah dilakukan menggunakan regresi maka dapat diketahui pengaruh antara variabel bebas dan terikat yaitu Upah Minimum Provinsi, Investasi, dan Produk Domestik Regional Bruto Terhadap Penyerapan Tenaga Kerja di Indonesia, sebagaimana berikut :

\section{Pengaruh Upah Minimum Provinsi (X1) Terhadap Penyerapan Tenaga Kerja (Y)}

Dari hasil estimasi yang telah dilakukan upah minimum provinsi menunjukan koefisien regresi sebesar 0.169971 dengan nilai probabilitas sebesar 0,0013 atau lebih kecil dari 0,05, artinya bahwa terdapat pengaruh positif dan signifikan antara upah minimum provinsi terhadap penyerapan tenaga kerja, setiap terjadi kenaikan upah sebesar 1\% maka akan meningkatkan penyerapan tenaga kerja sebesar 169971 ribu di Indonesia. Upah berpengaruh positif dikarenakan upah dapat meningkatkan permintaan tenaga kerja terdidik yang memiliki skill, keterampilan dan kualitas dalam bekerja, selain itu upah juga akan mendorong tenaga kerja untuk lebih produktif. Kenaikan upah juga akan berdampak pada peningkatan daya beli masyarakat, oleh karena itu naiknya daya beli akan berdampak pada meningkatnya produksi pada perusahaan, sehingga pengusaha akan menambah jumlah tenaga kerja yang dibutuhkan. Hal ini sesuai dengan penelitian Akmal (2010) upah minimum provinsi berpengaruh positif di karenakan dapat meningkatkan permintaaan tenaga kerja terdidik yang memiliki skill dan keterampilan akan tetapi disisi lain akan mengurangi tenaga kerja yang tidak memiliki keterampilan, berpendidikan rendah dan orang yang sudah tidak produktif dalam bekerja.

Hasil penelitian ini didukung oleh penelitian yang telah dilakukan oleh I Agung Indradewa (2015) dengan judul "Pengaruh Inflasi, Produk Domestik Regional Bruto dan Upah Minimum Terhadap Penyerapan Tenaga Kerja di Provinsi Bali", dalam penelitian menunjukan hasil bahwa upah minimum berpengaruh positif dan signifikan terhadap penyerapan tenaga kerja di provinsi Bali, kemudian penelitian yang dilakukan oleh Firiswandi (2016) menunjukan bahwa upah berpengaruh positif terhadap penyerapan tenaga kerja di Kota Medan, hasil ini juga diperkuat oleh 
penelitian yang dilakukan Azhar (2011) bahwa upah memiliki pengaruh positif dan signifikan terhadap penyerapan tenaga kerja di kab/kota di Jawa Timur.

Secara teori tidak sejalan dengan pendapat Kuncoro (2002) yang menyatakan kenaikkan upah dapat mengakibatkan penurunan kuantitas tenaga kerja yang diminta, jika tingkat upah mengalami kenaikan sementara harga input lainnya tetap maka harga tenaga kerja tersebut cenderung lebih mahal dari input lain, sehingga dapat mendorong pengusaha untuk mengganti tenaga kerja yang relatif mahal dengan input lain yang tentu harganya lebih murah guna untuk mempertahankan keuntungan. Hal ini sesuai dengan faktor-faktor yang mempengaruhi permintaan tenaga kerja berdasarkan Sonny Sumarsono (2009) yang menyatakan adanya perubahan tingkat upah dengan kenaikan upah dapat menaikan biaya pada perusahaan yang akan berdampak pada peningkatan harga produksi dengan naiknya harga produksi masyarakat akan mengurangi konsumsinya sehingga akan menyebabkan produksi yang tidak terjual, dengan turunnya jumlah produksi dapat menurunkan jumlah tenaga kerja.

\section{Pengaruh Investasi Terhadap Penyerapan Tenaga Kerja Di Indonesia}

Dari hasil estimasi yang telah dilakukan investasi menunjukan koefisien regresi sebesar -0.004752 dengan nilai probabilitas sebesar 0,0857 atau lebih kecil dari 0,05, artinya bahwa terdapat pengaruh negatif dan tidak signifikan antara investasi terhadap penyerapan tenaga kerja, setiap terjadi penurunan investasi sebesar $1 \%$ maka akan menurunkan penyerapan tenaga kerja sebesar 4752 ribu di Indonesia. Investasi berpengaruh negatif dikarenakan investasi yang dilakukan lebih bersifat kepadat teknologi atau modal dalam bentuk pembelian mesin yang dapat membantu dalam proses produksi yang lebih efektif dan efisien sehingga tidak terlalu menyerap tenaga kerja di Indonesia. Menurut pendapat Sukirno (1997) investasi merupakan pengeluaran yang dilakukan untuk pembelanjaan penanaman modal dan perlengkapan produksi yang digunakan untuk meningkatkan kemampuan dalam memproduksi barang dann jasa pada suatu perekonomian misalnya investasi berupa mesin dan teknologi yang mendukung dalam bekerja.

Hasil penelitian ini didukung oleh penelitian yang telah dilakukan oleh Febryana Rizky Wasilaputri (2016) dengan judul "Pengaruh Upah Minimum Provinsi, PDRB dan Investasi Terhadap Penyerapan Tenaga Kerja di Pulau Jawa" dalam penelitian menunjukan hasil bahwa investasi berpengaruh negatif tidak signifikan terhadap penyerapan tenaga kerja di pulau Jawa, kemudian didukung oleh penelitian Dimas dan Nenik (2009) dengan hasil bahwa investasi memiliki pengaruh negatif terhadap penyerapan tenaga kerja di DKI Jakarta hal ini di sebabkan karena banyak investasi yang cenderung memilih bersifat padat modal yang dirasa lebih efektif dan efisien dalam menghasilkan output.

Secara teori sejalan dengan pendapat Todaro (2003) yang mengatakan bahwa investasi memiliki hubungan negatif dikarenakan adanya akumulasi modal untuk membeli mesin serta peralatan canggih 
yang juga tidak hanya terjadi pemborosan keuangan domestik maupun devisa saja akan tetapi juga dapat menghambat pertumbuhan terciptannya lapangan kerja baru. Bagi investasi asing yang memiliki modal lebih cenderung untuk melakukan investasi padat modal karena akan lebih menguntungkan dibandingkan dengan investasi yang bersifat menyerap tenaga kerja untuk menghindari tekanan permintaan upah dari tenaga kerja serta untuk menghindari peraturan upah minimum yang berlaku untuk lebih meningkatkan keuntungan maksimum bagi para investor.

\section{Pengaruh Produk Domestik Regional Bruto Terhadap Penyerapan} Tenaga Kerja Di Indonesia

Dari hasil estimasi yang telah dilakukan produk domestik regional bruto menunjukan koefisien regresi sebesar 2.329450 dengan nilai probabilitas sebesar 0,0000 atau lebih kecil dari 0,05 , artinya bahwa terdapat pengaruh positif dan signifikan antara produk domestik regional bruto terhadap penyerapan tenaga kerja, setiap terjadi kenaikan produk domestik regional sebesar 1\% maka akan meningkatkan penyerapan tenaga kerja sebesar 2.329450 juta di Indonesia. Produk Domestik Regional Bruto berpengaruh positif dan signifikan dikarenakan hasil penjualan dari seluruh unit ekonomi mengalami kenaikan, dengan naiknya output penjualan akan berdampak pada peningkatan produksi karena semakin banyak output penjualan yang dilakukan maka perusahaan akan menambah jumlah tenaga kerja yang dibutuhkan untuk mengejar output penjualan yang diminta, sehingga semakin tinggi produk domestik regional bruto maka akan semakin banyak penyerapan tenaga kerja di Indonesia, asumsi Cateris Paribus.

Hasil penelitian ini didukung oleh penelitian yang telah dilakukan oleh Roni Akmal (2010) dengan judul "Analisis Faktor-faktor Yang Mempengaruhi Penyerapan Tenaga Kerja di Indonesia" dalam penelitian menunjukan hasil bahwa produk domestik regional bruto berpengaruh positif dan signifikan terhadap penyerapan tenaga kerja di Indonesia.

Secara teori sejalan dengan pendapat Keynes dalam Boediono (1998) yang menyatakan bahwa pasar tenaga kerja hanya mengikuti yang terjadi di pasar barang, apabila output yang di produksi naik maka jumlah tenaga kerja juga akan meningkat. Oleh sebab itu permintaan barang dan jasa dalam perekonomian dapat mempengaruhi tingkat output yang harus di produksi, sehingga dengan bertambahnya jumlah barang yang di produksi akan berdampak pada penggunaan tenaga kerja.

\section{KESIMPULAN}

Telah dilakukan dapat diperoleh beberapa kesimpulan yaitu penyerapan tenaga kerja di Indonesia pada tahun 2013-2017 kontribusi penyerapan tenaga kerja dengan rata-rata tertinggi berada pada provinsi Jawa Timur sebesar 16,75\%, Upah Minimum Provinsi dengan rata-rata tertinggi berada pada provinsi DKI Jakarta sebesar 4,78\%, sedangkan Investasi berada pada provinsi Jawa Barat sebesar 20,46\% , Produk Domestik Regional Bruto (PDRB) berada pada provinsi DKI Jakarta sebesar 16,10\%. Berdasarkan hasil uji regresi bahwa upah minimum provinsi menunjukan hasil positif dan 
signifikan terhadap penyerapan tenaga kerja artinya setiap terjadi kenaikan 1\% maka akan menaikan 169971 ribu penyerapan tenaga kerja di Indonesia, sedangkan investasi menunjukan hasil negatif dan tidak signifikan terhadap penyerapan tenaga kerja yang berarti ketika terjadi penurunan investasi sebesar 1\% maka akan menurunkan 4752 ribu penyerapan tenaga kerja di Indonesia kemudian PDRB menunjukkan hasil positif dan signifikan terhadap penyerapan tenaga kerja artinya setiap kenaikan 1\% PDRB maka akan menaikan 2,329450 juta penyerapan tenaga kerja di Indonesia.

\section{SARAN}

Berdasarkan hasil pembahasan dan kesimpulan maka dapat berbagai saran sebagai yaitu pembangunan yang dilakukan harus dapat merata di berbagai provinsi dan tidak hanya terpusat pada daerah tertentu sehingga kontribusi setiap provinsi dapat meningkat, upah minimum provinsi setiap tahun mengalami kenaikan, oleh sebab itu harus mendapatkan perhatian dan mempertimbangkan kebijakan yang akan dilakukan pemerintah, karena dengan kenaikan upah dapat menjadi beban bagi para pelaku usaha kemudian disisi lain juga harus memperhatikan kebutuhan hidup layak bagi tenaga kerja, sehingga harus lebih selektif dalam mengambil kebijakan. Investasi yang dilakukan harus bersifat tenaga kerja dan lebih selektif untuk memberikan perizinan bagi para pemilik modal, sehingga dapat terserap lebih banyak tenaga kerja yang nantinya dapat mengurangi pengangguran dan beban bagi pemerintah terkait ketenagakerjaan. Produk domestik regional bruto harus terus ditinggkatkan pada setiap sektor ekonomi di setiap daerah karena dengan meningkatnya produk domestik regional bruto dapat meningkatkan penyerapan tenaga kerja di Indonesia.

\section{DAFTAR PUSTAKA}

Akmal, R. (2010). Analisis Faktor-faktor Yang Mempengaruhi Penyerapan Tenaga Kerja Di Indonesia.

Atifatur, R \& Arfida, B.R. (2018). Analisis tingkat penyerapan tenaga kerja sektor industri di kabupaten gresik. Jurnal Ekonomi Pembangunan 2, 74-82.

Azhar, K., \& Arifin, Z. (2011). Faktor - Faktor Yang Mempengaruhi Penyerapan Tenaga Kerja Industri Manufaktur Besar Dan Menengah Pada Tingkat Kabupaten / Kota Di Jawa Timur. Jurnal Ekonomi Pembangunan, 9(1), 90.

Dumairy. 1996. Perekonomian Indonesia. Jakarta: Erlangga

Dimas, dan Nenik. (2009). Penyerapan Tenaga Kerja Di DKI JAKARTA Fakultas Ekonomi Universitas Diponegoro Semarang,

16(1), 32-41.

Firiswandi, P., Ekonomi, F., Bisnis, D. A. N., Negeri, U. I., \& Utara, S. (2016). Pengaruh Upah Dan Modal Terhadap Penyarapan Study Kasus Pusat Industri Kecil Menteng Kota Medan. 
Indradewa, I. G. A., \& Natha, K. S. (2015). Pengaruh Inflasi, PDRB, Dan Upah Minimum Terhadap Penyerapan Tenaga Kerja Di Provinsi Bali. Jurnal Ekonomi Pembangunan, 4(8), 923-950.

Kuncoro, Mudrajat. 2000. Mudah Memahami dan Menganalisis Indikator Ekonomi. Yogyakarta: UPP STIM YKPN Yogyakarta

Kuncoro, Haryo. 2002. Upah Sistem Bagi Hasil dan Penyerapan Tenaga Kerja. Jurnal Ekonomi Pembangunan: Kajian Ekonomi Negara Berkembang Vol. 7, No 1, 2002. ISSN: 1410-2641 hal 45-56

Noerdhus dan Samuelson. 2000. Ilmu Ekonomi Makro. Jakarta: Media Global Edukasi

Nofandillah, A. \& Aris, Soelistyo. (2018). Analisis Pengaruh Upah,Pdrb ,Dan Investasi Terhadap Penyerapan Tenaga Kerja Dikawasan Gerbangkertasusila Tahun 2012-2016. Jurnal Ekonomi Pembangunan, 2, 357371

Nurrohman, R., \& Arifin, Z. (2010). Analisis Pertumbuhan Ekonomi Dan Penyerapan Tenaga Kerja Di Provinsi Jawa Tengah. Jurnal Ekonomi Pembangunan, 8(1), 247.

Payaman J, Simanjuntak. 2001 Pengantar Ekonomi Sumber Daya Manusia. Jakarta: LPFE UI

Sukirno, Sadono. 1997. Pengantar Teori Makro Ekonomi. Jakarta: PT Raja Grafindo --- Persaja. 2005. Mikro Ekonomi Teori Pengantar edisi ketiga. Jakarta: PT. Rajagrafindo Persada.

Sumarsono, Sonny. 2009. Teori dan Kebijakan Publik Ekonomi Sumber Daya Manusia. Yogyakarta: Graha

Todaro, M.P dan Stephen C.S. 2003. Pembangunan Ekonomi di Dunia Ketiga: Edisi Kedelapan. Jakarta: Erlangga

Todaro, 2000. Pembangunan Ekonomi di Dunia Ketiga Trans Haris Munandar. Jakarta:Erlangga

Wasilaputri, F. R. (2016). Pengaruh Upah Minimum Provinsi, Pdrb Dan Investasi Terhadap Penyerapan Tenaga Kerja Di Pulau Jawa Tahun 2010-2014. Jurnal Ekonomi Pembangunan, 5(3), 243-250. 